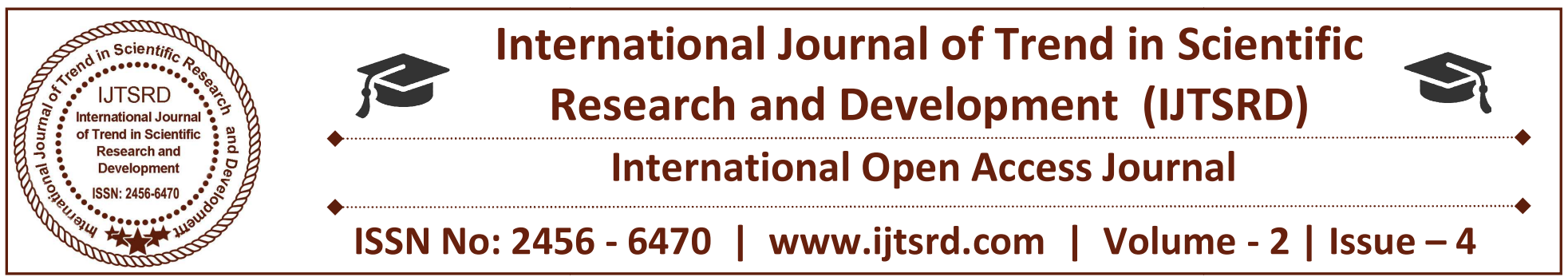

\title{
Impact of Private Tuition at Birsanagar Jamshedpur, Jharkhand
}

\author{
Mrs. Namrata Srivastava \\ Assistant Professor, Loyola B.Ed. College, Telco, \\ Jamshedpur, Jharkhand, India
}

\begin{abstract}
The main objective of this study was to know the attitude of students, parents, and private tutors regarding private tuitions. What is the impact of private tuitions on education? And also to study the contribution done by private tuituios for effective learning. Do tuitions help in scoring good marks? Private tuition boon or bane? Does private tuition also impacts on the fairness of our education system. The study was based on field work and survey method. The sample size for the study was 200.Respondents were parents teachers, students and private tutors. Data were collected mainly by interviews, questionnaire and observation. The questionnaire and interview was for the students and private tutors.
\end{abstract} Parents were only interviewed.

\section{INTRODUCTION}

As the aim of education is mainly the development of three domains i. e cognitive, affective and psychomotor. All the schools of Government and private sectors are subjected to fulfil this aim. But we really need to think what values are being developed in the process of teaching learning especially in schools. There are many reasons for corruption risks in the general education sector, some are in the area of truancy, education of knowledge, out of school private tutoring, school budget formation and implementation and school administration.

The researcher is mainly concern with the reason of out of school private tutoring. Do coaching centers and private tuitions help in scoring good marks? An hour a week with a tutor can help exam candidates to correct weaknesses. But private tuitions also impact on the fairness of our education system In an ideal world it might be better if private tuitions for exam

didn't exists. But it does, and we need more ideas for levelling out our uneven playing field of education system. Private tutoring can provide more individualised instructions than from the tutors of private schools, using a more flexible delivery mechanism The private tutoring industry is also differentiated from the private school sector, in that its existence depends on the main stream education system. This aspect of private tutoring helps explain why it has been referred to as "Shadow education"

Birsa Nagar is named after a tribal warrior Birsa Munda who fought against the British during India's freedom struggle. It is the biggest residential area in Jamshedpur. It started out as a huge illegal squatter settelement under the patronage of Kunjal Lakra and influencial tribal leader of Birsa Seva Dal. The building pattern of this area is irregular as the residences were privately constructed. Near Birsanagar many private and government schools run. Number of students are influenced or are motivated towards going for private tuitions. the investigator tries to find the impact of private tuitions.

\section{TITLE OF THE PROBLEM:}

Impact of private tuitions in secondary school children of Birsanagar in Jamshedpu, Jharkhand

\section{SIGNIFICANCE OF THE STUDY:}

In most of the government schools the teachers are less devoted to their duties. Their only duty is regarding teaching learning and this is only the missing thing or we can say failing day by day as a result students don't get desired success in academic performance. Every parents definitely want their child to grow up with more knowledge and thus ready to face the problems of life. This is the reasons why 
students are getting engaged in private tuitions. Do private tuition really help? This a million dollar question! Do tuitions help in scoring good marks? "Private tuitions -Boon or Bane? ".So in the present study the investigator tries to measure whether tuitions actually contribute to education or it is just a zero-sum game.

\section{OBJECTIVE:}

1. To study the attitude of students after joining any private tuition

2. To study the impact of private tuition on education system.

3. To study the contribution done by the private tuiotions.

\section{HYPOTHESIS:}

1. To find the effectiveness of private tuition on before and after joining tuition.

2. To find the effectiveness of private tuitions

\section{SAMPLE:}

Investigator's study concerned only within the area of Birsa Nagar. The investigator selected 200 respondents as sample comprising of parents, school teachers, students and private tutors.

\section{METHODOLOGY:}

The investigator adopted survey method to find the impact of private tuitions in Birsanagar.

\section{TOOL:}

The data are collected by interviews, questionnaire and observation. The questionnaire and interview was for students, parents and private tutors.

\section{STATISTICAL TECHNIQUES:}

Statistical techniques such as percentage analysis and arithmetic mean were used.

\section{DATA ANALYSIS AND FINDINGS:}

Marks obtained by sample of 20 students each who have joined and not joined tuitions respectively studied and the following results were observed

\section{HYPOTHESIS;}

1. There is no significant difference between the marks of people who are going to tuitions and who are not.

Null hypothesis

$\mathrm{H} 0$ :

$$
\mu_{1-} \mu_{2 \leq 0}
$$

Ha:

$$
\mu_{1-} \mu_{2>0}
$$

\section{Where}

$\mu_{1 \text { : mean marks of the group1 who are not going }}$ to the tuitions

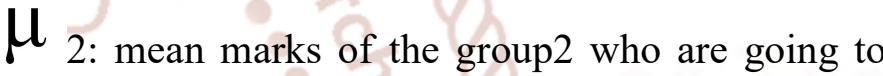
the tuitions

Scientific TABLE 1
\begin{tabular}{|l|l|l|}
\hline \multicolumn{1}{|c|}{ RESULTS } & Group 1 & Group 2 \\
\hline $\mathrm{N}$ & 20 & 20 \\
\hline Mean t & 49.900 & 59.900 \\
\hline Std Dev & 18.396 & 13.194 \\
\hline SE 170 & 4.113 & 2.950 \\
\hline Sp & 16.008 & \\
\hline T & -1.975 & \\
\hline
\end{tabular}

It is observed from the above table that the calculated ' $t$ ' value is more than 1.96 so we reject null hypothesis. Hence it is evident that there is significant difference of mean marks who are going for tuitions and who are not, the people who are going are having better performance in the subject, 
TABLE 2

CAUSES FOR OUT OF SCHOOL PRIVATE TUTORING

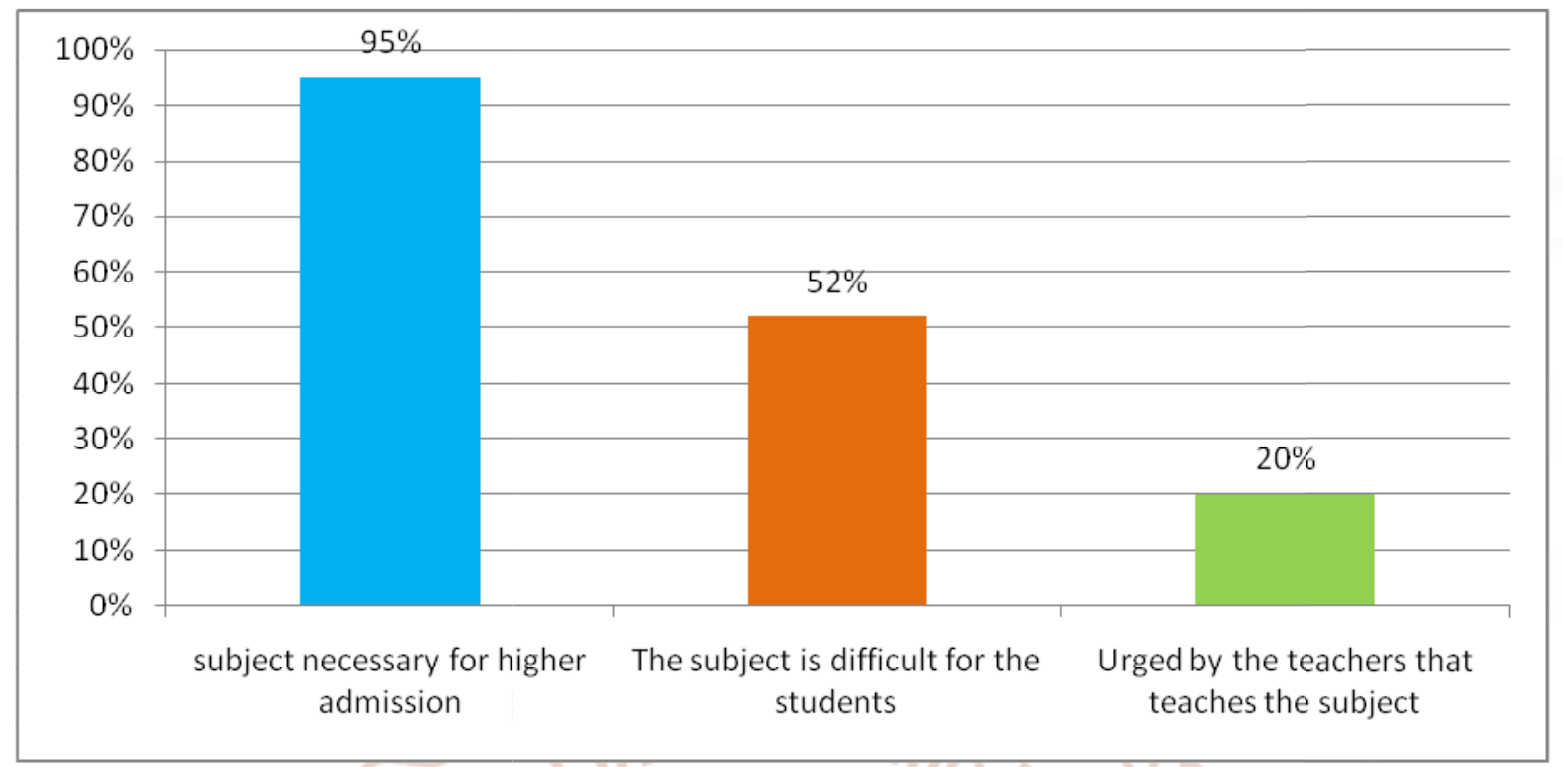

TABLE 3

\section{SUBJECT WISE TUITIONS PREFERRED TREND IN BIRSA NAGAR}

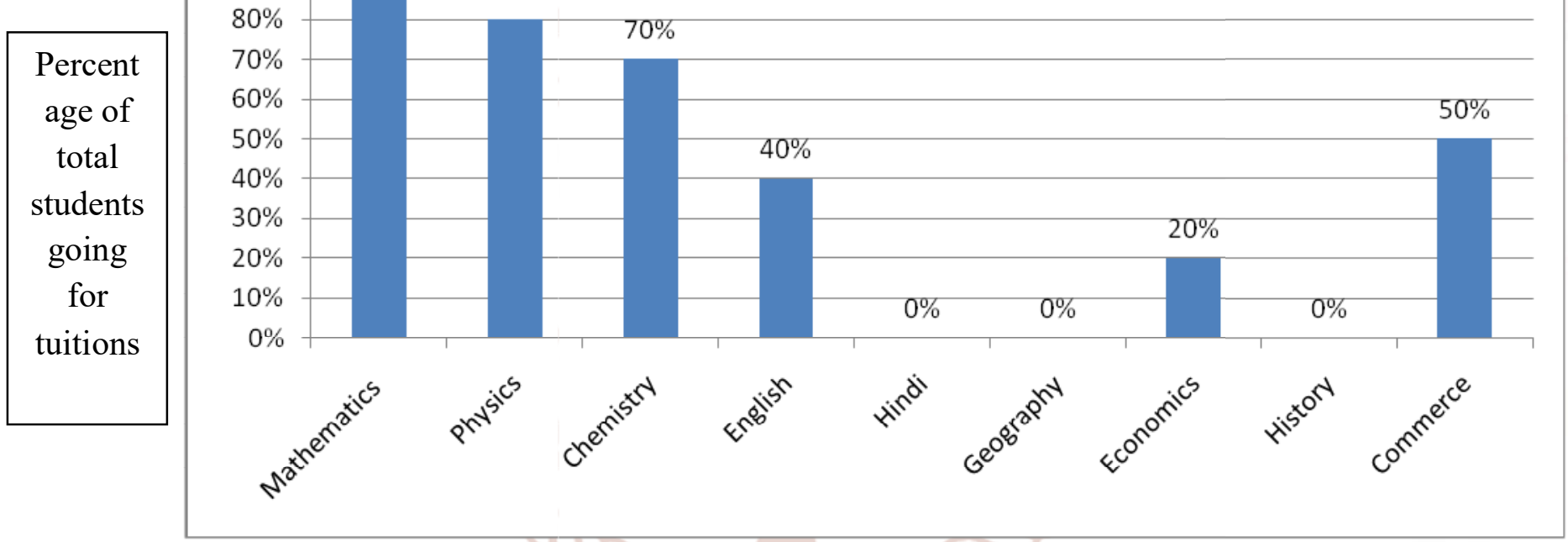

FINDINGS AND DISCUSSIONS:

Many students of birsanagar near Baridih and telco are engaged in private tuitions . This is just because they want to achieve better academic result. their main aim of going for private tuition is understanding the subject matter Though the same subject matter is taught to them by their school teacher in a parallel manner. Through tuitions doubts are clear and they may became a smooth learner and thus become more than the average students. Private tutors give full attention to their students because they come only to focus on their lessons. The researcher came to know that school education is not enough for students to cope with the present changing competitive atmosphere. They can opt for the private tuition to get their result better. After all it is the academic performance only which shows student's achievement, improvement and progress. After interaction with the students the researcher felt that many students feel confident in themselves, because now they may not lag behind their school teacher lessons.

\section{CONCLUSION:}

In this study the researcher finds that none of the parents want their child to be under achiever, and so they try to provide them all supports and means by which they can improve their their learning. very little 
time is being spent in the school for the subjects like science and mathematics. The researcher felt that engaging in tuition may really fulfil the requirements of the' individual difference'. Individual difference is an important factor for the blooming of private tuitions industry. Many students do truancy and are smart enough to cover the course or the topic in their private tuitions. This has led to the irregularity in the schools. It appears that tuition has strong positive impactas as a supplement to formal public school education. The researcher concluded that the private tutoring contributes to the human capital development and private tutoring is an effective means of tailoring education to the needs of the students.

\section{REFERENCE:}

1. HINDUSTAN Newspaper dated $30^{\text {th }}$ Jan'2011

2. KURUKSHETRA monthly magazine.

3. Kumar: Research methodology.

4. Koul, Lokesh: Methodology of educational research.

5. Sharma, R,A: Educational research.

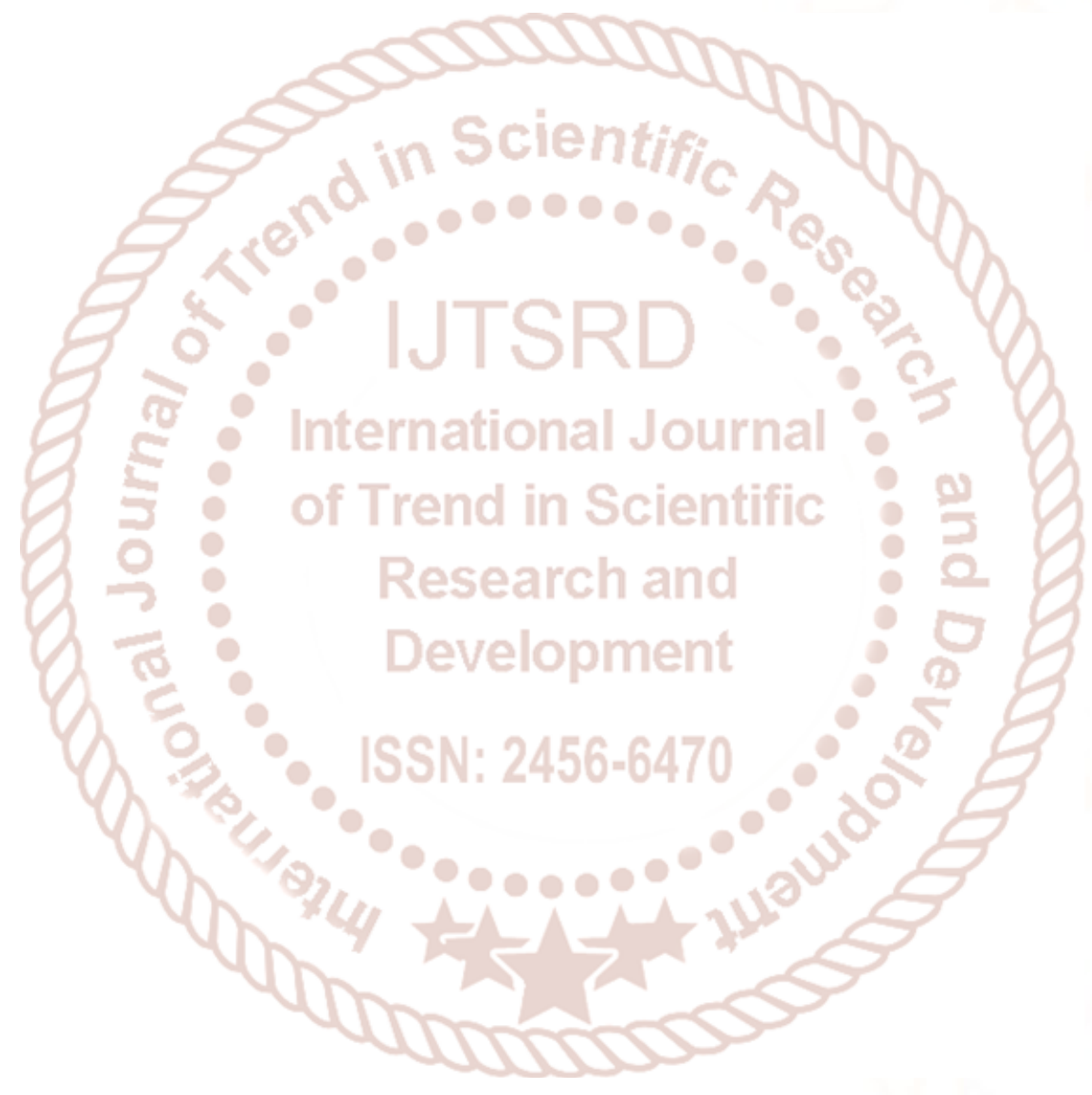

